\title{
Vanished in the Haze: White Elephants, Environmental Degradation and Circassian Marginalization in Post-Olympics Sochi
}

\author{
Bo Petersson \& Karina Vamling
}

Before the Olympic Winter Games in Sochi in 2014 there was an intense international discussion on the wanting Russian record on democracy and human rights and the appropriateness of organizing such mega-events in authoritarian settings. These kinds of discussions had a familiar ring to them; similar voices were heard before the Beijing Summer Olympics in 2008. However, what was notable in the scholarly discussion after the Beijing Olympics was a lack of substantiated follow-up with regard to political and social consequences of the Games. Once the Olympic Games were launched, the sports events themselves took over the public limelight. Further to this, media logics seem to dictate that once any Games are over, critical discussions are over and done with, and the attention is gradually shifted to the next mega-event to follow, in the Sochi case the Summer Games in Rio in 2016 and the FIFA World Cup in football which will be arranged in several locations in Russia in 2018. In the case of the Sochi Games, the fading from attention was exacerbated by the dramatic events which unfolded around Ukraine and the Russian role in them which came to dominate newscasts from a time when the Games had barely even been concluded.

With regard to Sochi, as for all sites of major sports events, continued critical attention is called for to assess political developments on the local, regional and central levels of the state even after the conclusion of the Games. It is essential to try to gauge the extent to which predicted problems materialized, what happened afterwards, and what have been the more long-term consequences for the local population and also in a wider regional perspective. Post-Olympic Sochi offers an interesting post of observation for scrutinizing local effects of meso-level policies and mega-event arrangements.

The need for a thorough follow-up to what actually befalls the host city after any Olympics can be argued for many reasons. When such a mega-event is organized in the setting of an authoritarian political system the need is exacerbated even further, and it could indeed be argued to be a duty on the part of critically minded scholars to continue to engage with the matters that have been of concern before the Olympics. Simple logic says that if these matters were of interest before the Olympics they should be so even after the circus has left the town. In this chapter, we will turn our attention to three areas that before the Sochi Olympics were 
often discussed as particularly acute problems in relation to the Olympics. The first one of these is related to infrastructural investments in the area and the risk of them being turned into so-called white elephants, costing a lot of money and being of no actual use, neither by the local population nor by tourists to the region. The second theme regards the feared environmental degradation due to the organization of the mega-event and the extent to which the prognosticated problems have come to materialize. These two are matters that in one shape or another seem to be brought up in relation to all Olympics in contemporary times, possibly with the exception of the Lillehammer Olympics of 1994 which were generally praised for its modesty, small-scale format and back-to-the roots quality (Taras 2013). The third theme, which enjoyed substantial attention before the Olympics, is however specially related to the Sochi Olympics. It deals with the indigenous Circassian population and the extent to which its members were maltreated, marginalized and squeezed out from the geographical area which constitutes their homeland. Despite their seeming disparity, the basic reason for bringing up the three subjects in the chapter is the same: to argue the need for continued attention to perceived trouble-spots even after the close of the Games.

The chapter follows up on an inventory, edited by the authors in the year before the Olympics, of perceived potential problems related to the Sochi Winter Games. That particular inventory took stock of what the authors of this piece chose to call the Sochi predicament (Petersson and Vamling 2013). The point that the authors would like to make is thus that this predicament still exists. The problems remain even though the world's attention has faded. In some respects the problems may have gotten more acute and it is vital not to leave the local population in the lurch.

Infrastructure and white elephants

During the run-up to the Olympics it was noted on several occasions on the highest political levels in Russia that infrastructural development in the region as a whole was a prominent governmental objective. Another aim was to successfully establish Sochi as a winter holiday resort for Russian as well as foreign tourists (Petersson 2014). In the discussion in the media about effects in Sochi and North Caucasus following Sochi-2014 some observers have indeed, on the side of benefits, noted modernizing effects such as higher standards of service and more well-organized reception of tourists and other visitors, and a markedly enhanced 
availability of cafés and sites of accommodation. All this, it has been argued, makes Sochi a destination that can compete with European resorts as far as facilities are concerned (Kuzmina 2014, Grebennikova 2014). Moreover, the Games have resulted in a huge capacity of luxury accommodation, both in the Olympic village and the city of Sochi but also in the mountains in Krasnaya Polyana.

On the face of it, the Olympics have indeed meant a general improvement of infrastructure in the Sochi region, both with regard to main roads, railroads, air traffic and marine transportation (Working meeting with Transport Minister Maxim Sokolov, 2014). In connection with the Olympic Winter Games, a sports university, the Russian International Olympic University, opened in Sochi. Fittingly, it was profiled towards management of sport mega-events, and it was funded by the Russian tycoon Vladimir Potanin's company Interros, which also owns the Roza Khutor complex in Krasnaya Polyana (Saakov 2014).

During the construction phase many commentators expressed doubts whether all arenas, hotels and other sites would be ready in time for the Games. As a matter of fact, they were. The demand for construction workers was huge during the run-up and attracted large numbers of migrant workers. According to Human Rights Watch (2013) over 16,000 workers from outside of Russia, mainly from Central Asia, worked on the different Olympic objects. Construction workers interviewed by a local NGO made serious complaints such as that "employers cheated workers out of wages, required them to work 12-hour shifts with few days off, and confiscated passports and work permits, apparently to coerce workers to remain in exploitative jobs” (Human Rights Watch 2013). One year after the end of the Games the issue of wage arrears to (now departed) migrant construction workers is still on the agenda. Human rights activists estimate salary debts that have not been paid to Sochi constructions workers to more than 30 million roubles (Krasov 2014). The migrant workers still try to act on their complaints, and appeals have been made to the Russian State Duma in the matter (Kavkazskii Uzel 2015).

In the post-Olympics phase Sochi faces the same problem as most, if not all, other Olympic sites: to find an effective and alternative use of the infrastructure that was created during a highly compressed period to meet a frantic demand which peaked during a very limited time. In this process the familiar problem of trying to avoid the emergence of white elephants is prone to appear. In the annual Direct Line broadcast live by Channel One, Rossiya- 1 and 
Rossiya-24 TV channels and the Mayak, Vesti FM and Radio Rossii radio stations, President Vladimir Putin was clearly annoyed when someone from the audience raised the question whether the Olympic Park area in Sochi was not in fact turning into a white elephant. The president reminded his listener that he had already elaborated on the subject and again assured that appropriate plans had been made for the sports facilities in the area: 'Some of them will be turned into exhibition centres, shopping malls; some will be used as concert halls; some ice rinks will still be used for their initial purpose', he remarked (Putin 2014b), even if this answer for an outside observer would seem to have a not altogether convincing touch to it.

Different estimates are given concerning the actual number of visitors to Sochi in the period after the Games. Not very surprisingly perhaps, many of the new hotels appear now to stand almost empty most of the time (Saakov 2014). In a somewhat unexpected turn of the discussion during the aforementioned Direct Line with Putin in April 2014, one listener expressed his fears that the incorporation of Crimea would have negative effects for Sochi since the competition for domestic Russian tourism would increase. Now, he argued, Russians not wishing or not being able to go abroad during their holidays would have one more destination to choose from. However, Putin reassured his audience, Sochi and Crimea were not likely to compete for the same segments of domestic tourism. Many tourists who would not be able to afford the price tags encountered in Sochi would opt for Crimea instead. In other words, Sochi with its top-notch hotels and luxury apartments would not focus on the same clientele as Crimea (Putin 2014b). Again, however, Putin’s insistence would rather seem to underline the risk for emergence of white elephants, especially as Russia at the time of his statement was hard hit economically by the combined effects of rapidly dropping oil prices, weak world economy and the consequences of Western sanctions against Russia in the wake of the Ukrainian crisis and the annexation of Crimea. So, who would really afford going to Sochi on holidays?

Endeavoring to host other sport events is otherwise an evident option for how to use newly built arenas and hotels. Already in October 2014 Sochi organized the Russian Formula-1 Grand Prix (Sochi Autodrom 2014), which is planned to be an annually recurring event. In November 2014 the World Chess Championship was arranged in Sochi (Feeney 2014) and in December the ice hockey tournament Channel One Cup 2014 was organized there (Petersson, R. 2014). In 2018 Sochi's Fisht Olympic Stadium will be used as one of the arenas during the FIFA World Cup in football. 
For its part the World Chess Championship brought in a somewhat unexpected manner back high politics to Sochi. In a public meeting with Putin, the President of the World Chess Federation, Kirsan Ilyumzhinov, heaped scorn on the defending World Champion, the Norwegian chess player Magnus Carlsen for at first, with reference to the political climate not being sufficiently calm, refusing to defend his title in Sochi. Not until Carlsen was threatened with being stripped of his title and having to face a fine of several millions of dollars did he accept Sochi as a venue. Also, Ilyumzhinov went on, all previous world champions of chess, including the oppositional Garry Kasparov, had been invited to attend the opening of the game. Many prominent former champions had accepted, whereas Kasparov in principle had been willing to come but had expressed doubts whether he would actually be permitted to leave again if he were to turn up. According to the website transcripts, this observation drew some laughter, and considering the presence of Vladimir Putin, it is likely that he too joined in the merriment. At least he remarked that Kasparov was very welcome to attend. Even if he had 'not turned out to be the most effective politician so far ... he is an outstanding chess player', Putin said (Meeting with heads of international sports organizations, 2014).

Environmental degradation

In economic terms Sochi-2014 was the most expensive Winter Games so far in Olympic history (Müller 2014). Most often the costs are measured in money alone, however. It is more rarely mentioned that Sochi-2014 is also likely to have been the most costly Games ever in terms of damage done to nature. The most serious environmental issues that occurred in connection with the Olympics during the years 2006-2013 are summarized in Caucasian Knot (2014) and in a report by Gazaryan and Shevchenko (2014).

A circumstance that stands out in the choice of Sochi as the venue for winter Olympic Games is that it relied on combining winter sports facilities with a subtropical coastal climate and an adjacent alpine zone, which made the construction works both complicated and expensive (Petersson and Vamling 2013). The Sochi region is also a region that is well-known for its ecological uniqueness, which posed additional challenges for the construction work. North of Sochi is the Sochi National Park, established already in 1983 as one of the first national parks in the Russian Federation. Further to the northeast is the Western Caucasus Reserve that was inscribed into the UNESCO World Heritage List in 1999 with the justification that "it is of 
global significance as a centre of plant diversity” and "the only large mountain area in Europe that has not experienced significant human impact, containing extensive tracts of undisturbed mountain forests unique on the European scale” (UNESCO World Heritage List). The Imeretian Lowlands, a coastal area in Adler where the Olympic coastal cluster was built, were well-known wetlands with unique flora and fauna and an important place for migratory birds (Genin 2013). Thus, notwithstanding the ecological uniqueness and sensitivity of both the mountain and coastal clusters, the authorities decided to build the Olympic infrastructure there, with little concern for environmental values that risked being lost. Notably, the detrimental environmental impact is glossed over in the official reports about infrastructural development in the Sochi region.

One area that has been particularly hard hit by the construction works is the banks of the river Mzymta that flows from Krasnaya Polyana to Adler by the Black Sea. For several years large quantities of gravel for construction works were extracted there (Ria Novosti 2009), resulting in changes in the relief of the riverbed. The Olympic project included the building of both a highway and a railroad, from Adler to Krasnaya Polyana, connecting the coastal and alpine Olympic complexes. In this process relict boxwood forests were cut down to make way for the modern highway. Not only were vast areas of these forests cut down, but remaining parts of the forests were severely damaged and dehydrated (Gazaryan 2010). It was later agreed that new trees were to be planted to try to make up for this. However, the situation was made even worse by the fact that devastating box tree moths were accidently introduced together with the new plants into the habitat of the Caucasian boxwood tree. Even though the damage was discovered already in 2012, no appropriate measures were undertaken and the insects spread beyond the Sochi area thereby threatening other relict boxwood forests in the Caucasus (Ekologicheskaya vakhta po Severnomu Kavkazu 2014).

The extraction of enormous quantities of sand and gravel have occurred not only in Mzymta but also in other mountain rivers. This has distorted the river banks and changed water levels, resulting in an increased number of mudslides and flooding. Akhshtyr is one example of a village in Sochi were all water disappeared (Kravchenko 2014b) due to the construction works. The disposal of waste from the huge building sites has been another problem. Dumps, some illegal, occurred in different places around the city (Digges 2014). Moreover, Sochi does not have sufficient capacity to take care of all its sewage, which means that some of the polluted water is flushed directly into the Black Sea (Kravchenko 2014a). 
During the initial phases of preparations for the Games the United Nations Environment Programme (UNEP) cooperated with the Organizing Committee of the Sochi Olympics. Starting in 2009, the Committee formulated action plans for the ecological development in four key areas: Zero Waste Games, Climate Neutral Games, Games in Harmony with Nature and Enlightenment Games (Action plans). The organization undertook six expert missions to Sochi and Moscow and issued recommendations on how to improve the environmental standards of the event. Some of the results achieved were that the sliding venues and the Olympic Mountain Village were relocated away from the UNESCO World Heritage site and that a restoration plan was set up for the Mzymta river basin (UNEP undated). Among concerns voiced already in the first mission report were that all the buildings and infrastructure had to be built from scratch with resultant high environmental impact - with the added uncertainty whether these brand-new structures would ever be adequately used after the Games (Sochi 2014 - UNEP Mission Report).

The authorities have claimed that the Olympic construction process has been fully in compliance with environmental standards, and Vladimir Putin has even asserted that water quality has improved in the river Mzymta thanks to the newly constructed roads that have made cars emit less exhaust fumes when passing up and down the mountain side (Putin 2014a). Some progress has no doubt been noted in the environmental area (Ria Novosti 2010) but the actual implementation has often been far away from the green standards that were set up before the Games (Time 2014). Environmental organizations have devoted much effort to the critical monitoring of the process.

WWF-Russia was one of the environmental organizations that together with Greenpeace gave advice to Sochi-2014 in the process of planning and implementation of the Games in accordance with green standards. WWF has long experience of working with environmental perspectives on sports events, including Olympic Games. However, in 2010 WWF-Russia and Greenpeace reached a point after which they decided not to continue and thus terminated their monitoring. On its webpage WWF-Russia comments on the main environmental mistakes occurring in connection with the Sochi Games (WWF-Russia undated):

The location for the sites was chosen incorrectly. From the environmental point of view, the decision was bad because the whole mountain cluster is located on the territory of the 
Sochi National Park. [...] Because of the haste, Olympic organizers did not conduct a topographic survey for construction. [...]Due to lack of basic environmental information about the area (ungulate concentration sites, migration routes), Sochi-2014 organizers did not implement any activities to at least partly compensate the damage. [...] Under the pretext of Olympic needs, the nature conservation legislation was significantly weakened, especially parts concerning protected nature areas and environmental assessment of construction projects. [...]The Government refused to fund the post-Olympic environmental rehabilitation program [...].

This was in other words a harsh evaluation. Environmental organizations, as in the case of WWF-Russia and Greenpeace, either withdrew from the monitoring and consulting on environmental issues, or have been downright harassed by the authorities, as in the case of North Caucasus Environmental Watch (NCEW). Several activists of the organization have been detained because of their protests against the environment degradation caused by the Olympics. For instance, during the very days of the Winter Olympics, the environmentalist Evgeny Vitishko was sentenced to three-year imprisonment (Caucasian Knot 2014a; The Guardian 2014), while others have been forced into exile. In the autumn of 2014 the Court of the Adyge republic decided to suspend the NGO North Caucasus Environmental Watch (NatPressb, 2014), which has since appealed to the High Court of the Russian Federation to have the sentence revoked. Court proceedings are to take place in April 2015

(Ekologicheskaya Vakhta 2015).

The Circassian issue - before Sochi, after Ukraine

For the Circassians and their situation as the marginalized and squeezed out indigenous population of Northwest Caucasus, the mega-event of Sochi also denoted an opportunity to have the world's attention for their plight. However, earlier research has shown that marginalized and socially excluded groups seldom profit from the organization of megaevents on their home ground (Minnaert 2012). Did this apply also to the Circassians and the Sochi Olympics? Or was there at least one local collective winner due to the organization of the Sochi Winter Games? 
The Circassian situation was therefore paradoxical in the sense that whereas this North Caucasian indigenous group fiercely opposed the very organization of the Winter Olympic Games in Sochi, the Games themselves meant a unique chance for the Circassians to make their voices heard internationally. During the run-up to the Olympics they all of a sudden had a global audience, large segments of which were ready and prepared to listen while they communicated their claims for recognition of their cause. This was quite simply their fifteen minutes of fame, a rare and short-lived period of celebrity and world-wide attention (Petersson \& Vamling 2013, 9).

2014, the year of the Sochi Olympic Games, was also the 150th anniversary of the end of the Russo-Caucasian war and the deportation of the Circassian population from the Northwest Caucasian Black Sea coast and inlands. To the Circassians, the Olympic Winter Games in Sochi and Krasnaya Polyana played a special role. After a long and fierce resistance to Imperial Russia's conquest of their part of the Caucasus the Circassians were in 1864 finally defeated by the tsarist troops in Sochi (Hansen 2013). Sochi was the last "capital" of the Circassians and it was in Kbaada (now Krasnaya Polyana) that the Russians held their victory parade, following the last battles. Sochi has therefore gained a special symbolic value for the Circassians. After the Russian victory most Circassians were forced into exile, resulting in a large diaspora residing mainly in today’s Turkey, Syria, Jordan and the United States. The brutal warfare against the Circassians and their deportation is viewed as genocide by today's Circassians. In the Sochi area today, Circassians live only in a few scattered villages and in North Caucasus predominantly in the republics Adygeya, Karachaevo-Cherkessia and Kabardino-Balkaria. According to the 2010 census (Vserossiiskaya perepis naseleniya 2010), the total number of Circassians (Adyghe, Cherkess and Kabardians) in the Russian Federation is 715,000. The Circassian diaspora is estimated to be two to five million (Hansen 2013).

In the turbulent years of Boris Yeltsin's presidencies, official Russia came close to recognizing the demands of the Circassians as legitimate. The parliaments of the two North Caucasian republics with the largest Circassian populations in 1992 (Kabardino-Balkaria) and in 1996 (Adygeya) adopted resolutions on the Circassian genocide. In 1994, at the $130^{\text {th }}$ anniversary of the end of the war, president Yeltsin characterized the Caucasian War of the 19th century as a "courageous struggle by the Caucasian peoples not only for survival on their native lands but also for the maintenance of their own culture”. At the time he also expressed readiness to approach the problems of repatriation, whereby "the return of the Caucasian 
emigrants to their historic homeland should be solved on an international level through negotiations between all parties concerned” (Adygi.ru 2011). At the time, Yeltsin connected his recognition to the simultaneous processes of construction of rule of law and the prioritization of human values going on in Russia (ibid). It is however a well-known fact that Putin's Russia is comparison has been characterized by the re-emergence of authoritarian policies. The contextual preconditions for the Circassian struggle are therefore vastly different between then and now. Indicatively, in May 2013, Circassian organizations appealed to Vladimir Putin and to the Federal Council of the Russian Federation to recognize the Circassian genocide by the Russian Empire during the Caucasian Wars (Adyge Heku 2013). In their appeal the Circassian organizations reminded President Putin of the position of his predecessor, so far however to no avail. And the rest has been silence.

The resistance against Sochi and Krasnaya Polyana as the venue for the Winter Olympics served as a strongly mobilizing force for the Circassians, both in the diaspora and in the North Caucasian republics of Adygea, Karachaevo-Cherkessia and Kabardino-Balkaria (Hansen 2013). The issue served to bring different groups of the diaspora together and strengthened, not least through the establishment of the oppositional nosochi.com website, transnational interaction in the diaspora (Kaya 2014). Since the Circassians were the only indigenous population of the Sochi region, they were deeply disappointed to be sidestepped during the Olympic opening ceremony in Sochi - as were indeed all other Caucasian nations (Kapaeva 2014). The official line was tough, however, and in a statement by President Vladimir Putin at a press conference during the Games not a trace of recognition of the legitimacy of the Circassian claims could be discerned. Instead, Putin stonewalled, and argued that the "Circassian factor" was used for undue attempts by the West to hamper and slow down developments in the Russian Federation itself:

A theory took shape in 'cold war' times - it was called the deterrence theory. This theory and practical actions were aimed at hindering the development of the Soviet Union. Unfortunately, now we are seeing the same thing - the remains of this deterrence theory tend to come out into the open here and there. Whenever Russia demonstrates any positive development, the appearance of a new strong player, of competition, is bound to cause concern in the economy, in politics and in the security sphere. We see attempts to deter Russia here and there. Unfortunately, this had to do with the Olympic project and the Circassian factor was used as an instrument. 
However, frankly speaking, as soon as I reased that such attempts are being made I did not have any doubt that this was a futile attempt. I know what the mood is among the Circassians, I know the leaders of the Circassian organizations personally, and I know what their attitude is to both their native land and to their home country - Russia. It was obvious for me that this had no prospect (Meeting with the Public Council, 2014).

This is for several reasons a revealing statement. Not only was there a discernible attempt at connecting Circassian protests with the Western encirclement that often used to be part of Soviet-time rhetoric and has been brought to life in an increasingly harsh political climate of $21^{\text {st }}$ century Putinism. The argumentation also contains an opening towards condemning the Circassian demands as orchestrated from abroad and thus the results of action by a fifth column inside the country. It connotes a stern warning to the Circassian opposition not to rock the boat or else face the consequences. There is also a visible opening towards explaining away and dismissing the Circassian complaints by claiming that moderate and mainstream elements of the Circassians do not subscribe to this line of activism. This particular element is in short a display of the classical politics of divide and rule.

Already two days before the Games were even closed, political events in Ukraine took over media attention and eclipsed the Circassian issue completely. This was the time of the mass killings at Maidan, the popular outrage against president Yanukovich and his ultimate ouster. The media in the West and in Russia were from now on only marginally interested in events in the North Caucasus. The Circassian plight was no longer hot news, not even news, to the global audience, and the fifteen minutes of fame were gone.

Even so, in the context of the Ukrainian crisis and the deteriorated relations between Russia and the West, the Circassians have continued to try to achieve that the acts once committed by tsarist Russia be more widely recognized as genocide. Quite clearly, however, the Circassians have become further marginalized in the bigger political game. Their voices are now barely audible due to the general noise on the line. In May 2014, on the eve of the $150^{\text {th }}$ anniversary of the end of the Russo-Caucasian war, the Circassian Political and Cultural International Center "Fitingha” (a Circassian organization based in Israel) together with representatives from different Circassian organizations in North Caucasus, turned to the Ukrainian parliament and president with an appeal to recognize the acts committed by the Russian Empire against the Circassian people as genocide (Circassia Times 2014). In June 2014 a second appeal to 
the same effect was sent to the Ukrainian leadership from Circassians in North Caucasus and abroad (Kapaeva \& Gutiakulova 2014). Their move to turn to the Ukrainian authorities for support of their cause is not likely to have increased their popularity in the Kremlin, though. The reason why the Circassians chose to make their appeal to Ukraine at this particular point in time was probably that the leaders in Kyiv had clearly embarked on a democratic political orientation and therefore were prone to support the Circassian cause (Shazzo 2014). Indicatively, commitments were made by representatives of the Ukrainian Radical Party in September 2014 and in February 2015 to raise the matter of recognition in the Rada, the Ukrainian parliament (NatPress 2015). The two appeals to Ukraine to recognize the Circassian genocide were also followed by an appeal from Circassians in ten countries to Polish leaders on the Independence Day of Poland, on November 11, 2014 (NatPress 2014a). However, so far Georgia is the only foreign country to have formally recognized the Circassian genocide (Parliament of Georgia 2011).

The Circassian movement in the homeland and in the diaspora includes numerous NGOs and activists with wide range of different political agendas: nationalists, sovereigntists, centrists, culturalists, and accommodationists (Zhemukhov 2012). Although the appeals to Ukraine and Poland seem to have had widespread support among the Circassians, there is a certain split between diaspora activists and radical representatives in the homeland, on the one hand, and more moderate and mainstream elements in the homeland, on the other. This was the kind of division alluded to by Putin in his statement. The moderate sentiments are represented by the prominent Circassian activist Asker Sokht, leader of Adyge Hase, i.e. the International Circassian Association branch of the Krasnodar region, who argues that the question of recognition is an internal issue that should be dealt with within the Russian Federation. This position is also shared by the Adyge Hase of Adygeya (Adzhieva 2014). However, Mukhamed Cherkesov, leader of Adyge Hase of Karachaevo-Cherkessia, supports the Circassian appeal to the Ukrainian leadership:

[W] have turned to the leadership of our country several times, we have asked for meetings. Unfortunately, Russia has answered us with silence. We have said that the "Circassian question" is an internal issue, but Russia has not heard us. [...] We were hoping that Russia finally would listen to us at the $150^{\text {th }}$ anniversary of the end of the Russo-Caucasian war, but... Having lost hope of that Russia would ever turn to the “Circassian question” many Circassian activists have begun to look for other ways. (Kapaeva and Gutiakulova 2014). 
Andzor Kabard, a well-known Circassian activist, also seems to side with this standpoint: "If you take Circassian activists who are citizens of Russia, then the level of support for the appeal to Ukraine is very high. In the diaspora, it’s even higher” (Adzhieva 2014, 40-41).

The Russian authorities have responded to the appeals to Ukraine and Poland with tighter restrictions on the activities of Circassian activists (Dzutsev 2014). For instance, the editor-inchief of NatPress, Aslan Shazzo, was interrogated at the Center for Fighting Extremism in Adygea for having published articles on the appeals (Natpress 2014c). In late July 2014, Timur Kuashev, an oppositional Circassian author, disappeared and was found dead on the following day (Shevchenko 2014). Earlier during the year Kuashev had approached the socalled "Circassian question" from a legal perspective and discussed a number of, according to his views, interrelated issues, such as the mass arrests of young Circassians protesting in Nalchik in early February under the banner of "Sochi - land of genocide”, the unwillingness of Russian authorities to grant Circassian refugees from Syria repatriation; and double standards evident when Russian passports were distributed to Russian-speaking citizens in and from Ukraine (Kuashev 2014).

Another case against a Circassian activist that has attracted attention was the persecution in 2014 of Andzor Akhokhov of Kabardino-Balkaria, who organized the protests in Nalchik on February 7 against the Sochi Games. According to his own testimony he was subjected to torture and police abuse during his detention. After his release the police searched his home on February 28 and criminal charges on illegal arms possession were raised against him. Despite pressure not to do so, in March 2014 Akhokhov made an official complaint to the Court and Ministry of Internal Affairs of Kabardino-Balkaria concerning the torture and abuse that he had been subjected to (Kavkazskii Uzel 2014). Akhokhov's case has gained attention also outside Kabardino-Balkaria. Protests were e.g. organized in Turkey in support of his case (Kapaeva 2014) and representatives from the Circassian diaspora in several countries signed a statement condemning the violence exerted by the Russian authorities. By way of a general characterization of the situation, actions against North Caucasian human rights organizations and other NGOs as well as individual activists continue as before, but with notably scant media coverage in Russia and outside it. 


\section{Conclusion}

As this discussion of some of the key problems that were anticipated to hit Sochi in connection with the Winter Olympics has shown, the legacy of the Games is a rather heavy one for the town and for the region. In the two first cases discussed, on the emergence of white elephants and on feared environmental degradation, problems were to a large extent anticipated and the organization of the Games was rightly feared early on by activists. The problems were predicted to occur, and occur they did. They continue to fester even in the absence of international attention, and it is vital not to forget this. The international community has an obligation here, not least in view of future mega-events that are likely to take place in other authoritarian states in the future.

Even if this basic obligation of course remains, the situation of the indigenous Circassians was somewhat different from the concerns about useless infrastructural overspending and environmental decay. For the powers-that-be, the Circassian activism and the international attention it evoked was no doubt one of the politically most vexing problems of the preparation phase, but for the Circassians themselves the occasion meant a rare chance to realize some collective goals and improve on their marginalized position in their homeland in particular and in the Russian Federation in general. The Sochi Games served as a strongly mobilizing factor for Circassians in the diaspora and also in the region itself; had it not been for the Games this mobilization and strengthening of the Circassian movement would not have taken place. The Sochi Olympics, both during the period before and during the Games themselves, brought the Circassians international media attention they would not have been able to obtain otherwise.

Events in Crimea and Eastern Ukraine have since had a profound influence on Europe, Russia and the Sochi region. In the wake of these dramatic developments the Circassian question, alongside with any remaining side effects of the capital injections forcibly made in the Sochi region in the run-up to the Olympics, seems completely to have vanished in the haze. For the international community it is again a moral obligation to keep up the attention and continue to have the region under scrutiny. The problems are still there even if they have become eclipsed by bigger events. 


\section{Literature}

“Action plans” undated UNEP. Accessed 22 January 22, 2015 http://hqweb.unep.org/ sport_env/sochi2014/action_plans.aspx.

Adyge Heku. 2013. “Obrashchenie cherkesskikh organizatsii Adygei, KChR i Krasnodarskogo kraya k Prezidentu RF i Federalnomu Sobraniyu RF.” May 2. Accessed January 24, 2015 www.aheku.net/news/society/3542.

Adygi.ru. 2011. "Obrashchenie Prezidenta RF B.N. Eltsina k narodam Kavkaza v svyazi co 130-letiem Kavkazskoi voine.” October 10. Accessed February 20, 2015 http://adygi.ru/index.php?newsid=9937.

Adzhieva , Zara. 2014. “Priznat genotsid.” Dosh, 3, 47, pp. 38-41. Accessed January 25, 2015) http://www.doshdu.ru/archive/3-47-2014.

Caucasian Knot. 2014. "Sochi Olympics: environmental problems.” February 12. Accessed December 15, 2014 http://eng.kavkaz-uzel.ru/articles/27277/.

Circassia Times. 2014. "Rukovodstvu Ukrainy napravlena prosba priznat genotsid cherkesov Rossiiskoi imperiei.” May 21. Accessed January 5, 2015

http://circassiatimesrussian.blogspot.se/2014/05/blog-post_22.html.

Digges, Charles. 2014. “Olympic gashes and landfills cleave nature, and locals’ hearts.” Bellona January 30. Accessed January 4, 2015

http://bellona.org/news/russian-human-rights-issues/2014-01-olympic-gashes-landfillscleave-nature-locals-hearts.

Dzutsev, Valery. 2014. "Moscow Imposes Tighter Restrictions on Circassian Activists.” Eurasia Daily Monitor December 3. Volume: 11 Issue: 215. Accessed December 15, 2014. www.jamestown.org/regions/thecaucasus/single/?tx_ttnews[tt_news]=43145\&tx_ttnews[back Pid] $=639 \& \mathrm{cHash}=783192274 \mathrm{ddc} 04 \mathrm{f} 863 \mathrm{fe} 35 \mathrm{f} 8 \mathrm{a} 28 \mathrm{cb} 0 \mathrm{e} 0 \#$.VKpeACeVKIV .

Ekologicheskaya vakhta po Severnomu Kavkazu. 2014. "Ocherednoi 'podarok' sochinskoi olimpiady: samshitovye lesa Kavkaza - pod ugrozoi ischeznoveniya!” September 1, 2014. Accessed December 20, 2014 www.ewnc.org/node/14848.

Ekologicheskaya vakhta po Severnomu Kavkazu. 2015. 15 aprelya v Kirsanove i Moskve sostayatsa dva suda - po delam ob osvobozhdenii Vitishko i likvidatsii Ekologicheskoi vakhty, Accessed 15 April, 2015, http://www.ewnc.org/node/17796.

Feeney, Nolan. 2014. "World Chess Championship begins in Sochi.” Time November 9. Accessed January 4, 2015 http://time.com/3574733/chess-championship-sochi/.

Gazaryan, Suren. 2010. “Sovremennaya doroga 'Adler-Krasnaya Polyana' unichtozhila mzymtinskii sashitovi les.” Ekologicheskaya vakhta po Severnomu Kavkazu August 5, 2010. Accessed December 15, 2014 www.ewnc.org/node/5634

Gazaryan, Suren and Dmitrii Shevchenko. 2014. Sochi 2014: Ten years without the rule of law. How "a better world" was built. A report on the ecological impacts of the 2014 Olympic 
Games. February 21. Accessed December 16, 2014

www.greengrants.org/?attachment_id=12218.

Genin, Yulia. 2013. "Imeretinskaya Lowland is another environmental crime in preparation to Sochi 2014.” Sochi Watch July 2. Accessed January 4, 2015 http://sochiwatch.org/ 2013/07/02/imeretinskaya-lowland-is-another-environmental-crime-in-preparation-to-sochi2014/.

Grebennikova, Uliana. 2014. “Komu v Sochi posle Olimiady zhit khorosho.” Ria Novosti October 15. Accessed January 4, 2015 http://ria.ru/society/20141015/1028363463.html.

The Guardian. 2014. "Sochi environmentalist jailed for three years for spray-painting a fence.” February 12. Accessed February 18, 2015 www.theguardian.com/environment/ 2014/feb/12/sochi-environmentalist-jailed-painting-fence-revenge.

Hansen, Lars Funch. 2013. “Sochi as a Site of Circassian Long-Distance Memorialisation.” in The Sochi Predicament: Contexts, Characteristics and Challenges of the Olympic Winter Games in 2014, edited by Bo Petersson and Karina Vamling. Newcastle upon Tyne: Cambridge Scholars Publishing, 95-123.

Human Rights Watch. 2013. "Russia: Migrant Olympic Workers Cheated, Exploited.” February 6. Accessed January 28, 2015 www.hrw.org/news/2013/02/06/russia-migrantolympic-workers-cheated-exploited.

Justice for North Caucasus. 2014. "Statement of Denunciation and Condemnation about Russian Authorities' Repressive Violations Against the Circassian Activist Andzor Akhokhov.” December 16. Accessed February 20, 2015 http://justicefornorthcaucasus.info/?p=1251673792.

Kuzmina, Nadezhda. 2014. "Olimiada , 100 dnei spustya. Kak izmenilsya kurortnyi Sochi.” Argumenty i Fakty June 2. Accessed December 15, 2014 www.aif.ru/sport/olymp/1181302.

Kapaeva, Asia. 2014. "V Stambile bole shestidesyati chelovek vyshli na aktsiyu protiv presledovaniya organizatora antiolimpiiskoi aktsii v KBR.” Kavkazskii Uzel June 22. Accessed January 4, 2015 http://kabardino-balkaria.kavkaz-uzel.ru/articles/244679/.

Kapaeva, Asia and Irina Gutiakulova. 2014. “Ukraina i genotsid cherkesov.” Politika09 August 7. Accessed January 5, 2015 http://politika09.com/vlast-i-obshhestvo/ukraina-igenotsid-cherkesov/.

Kavkazskii Uzel. 2014. “Organizator aktsii v Nalchike protiv Olimpiady obratilsya v TsK i prokuraturu s zayavleniem o pytkakh.” March 14. Accessed February 22, 2015 www.kavkazuzel.ru/articles/239485/.

Kavkazskii Uzel. 2015. "Stroiteli v Sochi zayavili o nevyplate im dolgov za stroitelstvo olimpiiskikh obektov.” January 9. Accessed December 20, 2014 www.kavkazuzel.ru/articles/255320/.

Kaya, Ayhan. 2014. "The Circassian Diaspora In and Outside Turkey: Construction of Transnational Space in the Post-Communist Era." Problems of Post-Communism, 2014, 61: 50-65. 
Krasov, Oleg. 2014. "Rights defenders: in preparation for Sochi Olympics rights of over 1500 migrant workers were violated.” Caucasian Knot May 21. Accessed December 20, 2014 http://eng.kavkaz-uzel.ru/articles/28194/.

Kravchenko, Svetlana. 2014a. "Sochi: untreated sewage drained into sea.” Caucasian Knot February 21. Accessed December 15, 2014 http://eng.kavkaz-uzel.ru/articles/27359/.

Kravchenko, Svetlana. 2014b. "Sochi Akhshtyr villagers complain about absence of water and poor ecological state of the district." Caucasian Knot May 26. Accessed December 14, 2014 http://eng.kavkaz-uzel.ru/articles/28247/.

Kuashev, Timur. 2014.“Cherkessii vopros - vopros prava.” Kabardino-Balkarskij respublikanskij pravozashchitnyj tsentr June 10. Accessed December 10, 2014

http://zapravakbr.ru/index.php?option=com_content\&view=article\&id=352:2013-07-19-1008-33 (republished from the journal Dosh, Vol. 46, No 2, 2014).

Meeting with heads of international sports organizations. 2014, 9 October. Accessed January 9, 2015 http://eng.kremlin.ru/news/23066.

Meeting with the Public Council for the Preparation of the 2014 Winter Olympics, February 10, 2014. Accessed February 17, 2015 http://eng.kremlin.ru/news/6642.

Minnaert, Lynn. 2012. “An Olympic legacy for all? The non-infrastructural outcomes of the Olympic Games for socially excluded groups (Atlanta 1996-Beijing 2008).” Tourism Management 33:2, 361-370.

Müller, Martin. 2014. “Introduction: Winter Olympics Sochi 2014: what is at stake?” East European Politics, 30:2, 153-157.

NatPress. 2014a. "A request to recognize the Circassians genocide was sent to Poland on its Independence Day.” November 13. Accessed December 14, 2014 www.natpressru.info/ index.php?newsid=9244.

NatPress. 2014b. "Grazhdanskii forum ES - Rossiya osudil likvidatsiyu 'EkoVakhty po Severnomu Kavkazu’.” December 7. Accessed January 5, 2015 www.natpressru.info/ index.php?newsid=9292.

Natpess. 2014c. “Glavu 'Natpress' snova vyzyvali v tsentr 'E' po prosbam priznat genotsid cherkesov.” November 21. Accessed December 15, 2014 www.natpressru.info/ index.php?newsid=9266.

NatPress. 2015. "V Ukraine rabota po priznaniyu cherkesskogo genotsida prodolzhaetsya." February 17. Accessed February 20, 2015 www.natpressru.info/index.php?newsid=9416. 
Parliament of Georgia. 2011. "Resolution of the Parliament of Georgia On the Recognition of Genocide of Circassians by the Russian Empire.” May 31.

http://parliament.ge/en/media/axali-ambebi/resolution-of-the-parliament-of-georgia-on-therecognition-of-genocide-of-circassians-by-the-russian-empire-28184.page (accessed on 20 February 2015).

Petersson, Bo. 2014. "Still Embodying the Myth? Russia’s Recognition as a Great Power and the Sochi Winter Games.” Problems of Post-Communism 61:1, 30-40.

Petersson, Bo \& Karina Vamling. 2013. “The Sochi Winter Olympic Games: Walking a Tightrope?”, Bo Petersson \& Karina Vamling (eds): The Sochi Predicament: Contexts, Characteristics and Challenges of the Olympic Winter Games in 2014. Newcastle upon Tyne: Cambridge Scholars Publishing, 1-19.

Petersson, Robert. 2014. “Där lägger ryssarna Channel One Cup i år.” Hockeysverige.se August 26. Accessed January 4, 2015 www.hockeysverige.se/2014/08/26/dar-lagger-ryssarnachannel-one-cup-i-ar/.

Putin, Vladimir. 2014a. "Meeting with the Public Council for the Preparation of the 2014 Winter Olympics.”, February, 10. Accessed February 17, 2015 http://eng.kremlin.ru/news/6642.

Putin, Vladimir. 2014b. “Direct Line with Vladimir Putin”. Accessed January 9, 2015 http://eng.kremlin.ru/news/7034.

Ria Novosti. 2009. "MPR poprosit proverit zakonnost zabora grunta iz reki vozle Sochi.” March 3. Accessed January 5, 2015 http://ria.ru/eco/20090313/164699608.html.

Ria Novosti. 2010. "Ekologi uvideli pozitivnye izmeneniya v stroitelstve obektov v Sochi." December 17. Accessed January 4, 2015 http://ria.ru/eco/20101217/309968702.html.

Formatted: English (United States)

Shevchenko, Maksim. 2014. "Ubit Timur Kuashev - proshcheniya net i ne budet.” Kavpolit August 1. Accessed December 15, 2015 http://kavpolit.com/blogs/shevchenkomax/6170/.

Saakov, Rafael. 2014. "Sochi posle Olimpiady: gonki, khokkei i universitet.” BBC Russian Service October 22. Accessed January 5, 2015 www.bbc.co.uk/russian/sport/2014/10/141021_sochi2014_russia_olympics_legacy.

Shazzo, Aslan. 2014. "Pochemu cherkesy obratilis k Ukraine s priznaniem genotsida imenno seichas.” NatPress July 23. Accessed December 12, 2014. www.natpressru.info/index.php?newsid=9070.

Sochi 2014 - UNEP Mission Report, www.unep.org. Accessed January 5, 2015 hqweb.unep.org/.../sochi2014/.../First\%20Mission\%20Report.Sochi.Final.pdf.

Sochi Autodrom. 2014. "Formula 1 Drivers open up on the first day of 2014 FORMULA 1 RUSSIAN GRAND PRIX.” October 10. Accessed January 4, 2015 http://sochiautodrom.ru/en/news/circuit?id=460. 
Taras, Raymond. 2013. “Snow, Ice, and Vertical Drops: What is Different about the Sochi Winter Games?”, Bo Petersson \& Karina Vamling (eds): The Sochi Predicament: Contexts, Characteristics and Challenges of the Olympic Winter Games in 2014. Newcastle upon Tyne: Cambridge Scholars Publishing, 20-40.

Time. 2014. “The Not So Sustainable Sochi Winter Olympics.” January 30. Accessed January 4, 2015. http://time.com/2828/sochi-winter-olympics-environmental-damage/.

UNEP. Undated. “Green Olympics in Sochi.” Accessed January 5, 2015 www.unep.org/roe/ GreenOlympicsinSochi/tabid/54610/Default.aspx.

UNESCO World Heritage List. “Western Caucasus Western Caucasus.” Accessed January 5, 2015 http://whc.unesco.org/en/list/900.

Vserossiiskaya perepis naseleniya. 2010. Accessed February 20, 2015 www.gks.ru/free_doc/ new_site/ perepis2010/croc/perepis_itogi1612.htm.

Working meeting with Transport Minister Maxim Sokolov. 2014. March 14. Accessed January 9, 2015 http://eng.kremlin.ru/news/6849.

WWF-Russia. Undated. “Mistakes of Sochi-2014.” Accessed January 5, 2015 http://wwf.ru/about/positions/sochi2014/eng.

Zhemukhov, Sufian. 2012. "The Birth of Modern Circassian Nationalism,” Nationalities Papers, 40:3, 502-524 